\title{
Recent global trends in forest tenures
}

\author{
by Shashi Kant ${ }^{1}$
}

\begin{abstract}
Wide-ranging changes in forest tenures have occurred globally in recent decades, and the changes in developed countries and transition economies have been dominated by market forces. Market-based forest tenure changes are discussed in 4 categories: (i) forest management by a state-owned company (Sweden); (ii) commercialization, corporatization, and privatization of plantations (New Zealand, South Africa and Australia); (iii) creation of forest enterprises within state forestry agencies (the United Kingdom, Germany, and transition economies); and (iv) changes in forest tenures in economies in transition. The global tenure changes provide no empirical evidence in support of any specific form of tenure. I suggest 9 guiding principles, instead of a specific type of tenure, for forest tenure reform in Canada. Forest reforms should be organized: (i) keeping the future of forestry in perspective; (ii) for multiple attributes of forests; (iii) to provide flexibility, diversity, and adaptiveness; (iv) to foster forest industry competitiveness; (v) for economically optimal timber supply; (vi) to maximize the value of harvested timber; (vii) to recognize and deal with the non-separation of forest management and timber allocation and harvest; (viii) to select an appropriate organizational form, such as state business enterprise, corporation, or state-owned company, based on a SWOT (strengths, weaknesses, opportunities, and threats) analysis; and (ix) to seek inputs from an expert group-without direct stakeholders.
\end{abstract}

Key words: Australia, Canada, commercialization, corporatization, forest enterprise, forest tenure, Germany, New Zealand, privatization, South Africa, Sweden, transition economies, United Kingdom

\section{RÉSUMÉ}

Au cours des dernières décennies, de vastes changements dans les modes de tenure forestière se sont produits à léchelle mondiale et les changements dans les pays développés et les économies en transition ont été dominés par les forces du marché. Je présente des changements de mode de tenure forestière basés sur le marché dans quatre (4) catégories : (i) gestion forestière par une entreprise détenue par l'État (Suède); (ii) commercialisation, corporatisation et privatisation des plantations (Nouvelle-Zélande, Afrique du Sud et Australie); (iii) création dentreprises forestières à lintérieur des agences forestières étatiques (Royaume-Uni, Allemagne et économies en transition); et (iv) changements des modes de tenure forestière dans des économies en transition. Les changements mondiaux en tenure forestière ne fournissent aucune preuve empirique pour appuyer une forme spécifique de mode de tenure forestière. Je suggère neuf (9) principes directeurs, plutôt qu'un mode précis de tenure, pour la réforme de la tenure au Canada. Les réformes forestières devraient être organisées : (i) en gardant lavenir de la foresterie en perspective; (ii) pour de nombreux attributs des forêts; (iii) pour fournir la flexibilité, la diversité et l'adaptivité; (iv) pour favoriser la compétitivité de l'industrie forestière; (v) pour l'approvisionnement économiquement optimal en bois d’oeuvre; (vi) pour maximiser la valeur du bois d’oeuvre récolté; (vii) pour reconnaître et s'assurer que la gestion forestière et l'allocation et la récolte de bois doeuvre ne sont pas séparées; (viii) pour choisir un modèle organisationnel approprié, comme une entreprise commerciale étatique, une société, une entreprise

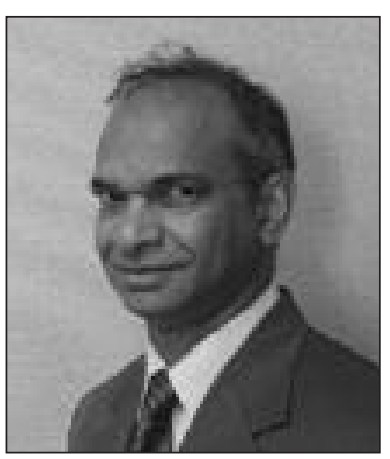
étatique, basée sur une analyse FFPM (forces, faiblesses, possibilités et menaces); et (ix) pour obtenir les recommandations d'un groupe d'experts - sans intervenant direct.

Mots clés : Australie, Canada, commercialisation, corporatisation, entreprise forestière, mode de tenure forestière, Allemagne, Nouvelle-Zélande, privatisation, Afrique du Sud, Suède, économies en transition, Royaume-Uni

Shashi Kant

${ }^{1}$ Professor, Forest Resource Economics and Management, Faculty of Forestry, University of Toronto, 33 Willcocks Street, Toronto, Ontario M5S 3B3. E-mail: shashi.kant@utoronto.ca 


\section{Introduction}

In the first paper of this series (Kant 2009), I discussed the issue of forest land ownership. The focus of this paper is forest tenure. In the Canadian context "forest tenure" is sometimes interpreted as the provincial governments' mechanisms for timber allocation from Crown forests, but these mechanisms are only one element of forest tenure. Forest tenure is a broad concept and includes forest ownership as well as management and allocation or distribution of all ecosystem goods and services provided by forests. In the broadest sense, forest tenures are property rights arrangements related to forest resources. "Rights" can never exist without associated "duties" and, therefore, forest tenures are specifications of "rights" and "duties" related to forest resources. For example, in Ontario, timber harvesting rights are allocated to private companies through Sustainable Forest Licenses (SFLs), and these SFL holders have many duties with respect to timber harvesting as well as forest management, road maintenance, monitoring and reporting. These duties are specified through SFLs and other instruments such as the Crown Forest Sustainability Act, the Forest Management Planning Manual, and various guidelines related to forest management. All these instruments, which specify rights and duties of SFL holders, are integral parts of forest tenures. Forest tenures are complex sets of rights and duties for all groups associated with forest land.

The complexity of forest ecosystems further enhances the complexity of forest tenures. Until the late 1980s, forest management in Canada was considered as timber harvest scheduling only, and the focus of forest tenures was the specification of rights and duties associated with timber only. However, with the emergence of the concept of Sustainable Forest Management (SFM), the focus of forest management has shifted from timber harvesting to management of forest ecosystems. This fundamental shift in the concept of forest management has resulted in new legal instruments for forest management, such as the Crown Forest Sustainability Act (1994) in Ontario and new forest tenure arrangements elsewhere in Canada.

There is a dominant belief among academics that provincial governments have not risen to the challenge of SFM by developing new and innovative tenure arrangements (Haley and Nelson 2007), and that forest tenure systems may have played a significant role in the decline of the Canadian forest industry (Minister's Council on Forest Sector Competitiveness 2005). The dominant proposed cause for the unsatisfactory performance of existing tenure systems is an increase in the duties of tenure holders, leading to enhanced compliance costs that result in high timber production costs (Haley 1996 and Clarke 1997). However, this evaluation is based only on a component (timber-related) of the economic perspective of SFM and there is no consideration of ecological and social dimensions. In a very informative study, $\mathrm{Lu}$ (2008) evaluated the effects of tenure characteristics on maintaining or enhancing competitiveness, environmental integrity and community stability (all dimensions of SFM) through a survey of 127 industry and 36 government representatives across Canada. He found that respondents were satisfied with some of the current tenure characteristics while indifferent to others. In addition, for improvement to forest tenures, respondents consistently agreed that attenuating tenure characteristics would negatively affect competitiveness but they held differing perceptions with respect to environmental integrity and changing tenure characteristics. Similarly, many scholars have argued that lack of security of tenure has a negative impact on competitiveness and sustainability of forests (Haley and Nelson 2007). However, Lu (2008) found that industry representatives were satisfied with the current duration of tenure. Arnot (2007), using data from a Canadawide survey of 107 forest tenure holders, found that perceived incentives for investment in timber-processing facilities, but not in forest management, are influenced by overall security of tenure. Hence, security of tenure may have different implications for competitiveness and environmental dimensions of SFM.

These and many other similar findings, which contradict simple theoretical economic arguments, suggest that the issue of Canadian forest tenures is not a simple economic text book case, and that it involves multiple dimensions-multiplicity of forest resources attributes, diverse characteristics of stakeholders, the 3 dimensions of SFM, and dynamics of all these dimensions. For example, forest resources have multiple attributes; some of these are private goods, such as timber; some are public goods, such as environmental and ecological services; some are common-pool goods, such as fruits, berries and leaves; and some are club goods, such as recreation. The presence of these multiple attributes, specifically public goods, means that market mechanisms alone may not be able to produce socially optimal outcomes and government regulation may be necessary to correct externalities. Similarly, markets are emerging for new goods and services, such as biocomposites, bio-chemicals, bio-energy, carbon, watershed services, and biodiversity, while the markets for such traditional forest products as pulp and paper and softwood lumber products are shrinking. In addition, new players such as Brazil, China, Indonesia and Malaysia are emerging in existing markets for traditional products, such as pulp. Hence, the focus of forest tenure discussions should be to develop the basic design principles of forest tenures to meet future challenges. We can learn from our experiences and other countries' experiences, but we should not try to replicate others' tenure systems because the future will be totally different than the past. Similarly, we should not argue to modify our tenure systems because other countries have done so. Our focus should be on designing innovative tenure systems in Canada that will provide socially optimal outcomes in emerging local and global social, environmental, and economic conditions.

The main purpose of this paper is to make a serious move in the direction of designing innovative tenure systems in Canada, and not to provide a specific framework for future forest tenures in Canada. I will provide an overview of trends in forest tenures at the global level and will present few key elements of future forest tenures. The remaining paper is presented in 3 sections: a review of forest tenures, key features of global forest tenure reforms, and proposed key elements of future forest tenures in Canada.

\section{Recent Global Trends in Forest Tenures}

In forest tenures generally, similar to other institutions, changes are incremental with few drastic changes. During the 1980s and 1990s, however, the intensity of change in forest tenures was much higher than in previous decades. Two opposing factors-one focused on market forces and 
economic efficiency and the other on rights and livelihood of rural, tribal, and forest-dependent people-were dominant during these 2 decades, but they were complemented by ecological factors, particularly after the 1992 Rio Summit. The 2 dominant factors resulted in 2 different patterns in the change of global forest tenures. In developed countries, forest tenure changes were dominated by market forces while in developing countries local peoples' rights were the dominant factor. In this paper, the focus is on market forces, and I categorize market-induced tenure changes in 5 categories: (i) change in forest land ownership; (ii) forest management by a state-owned company; (iii) commercialization, corporatization, and privatization of plantations; (iv) creation of forest enterprises within state forestry agencies; and (v) change in forest tenures in transition economies. Changes in forest landownership were discussed in the first paper of this series (Kant 2009) and the other 4 categories are discussed next.

\section{Forest management by a state-owned forest company in Sweden}

The Swedish Forest Service (Domänverket) was established in 1859 and one of its objectives was to increase the area of state-owned forest land. In the 1940s and early 1950s there was discussion about privatizing the state forestry agency but the government rejected the proposal. In 1992, however, Domänverket (responsible for forest land and operations) was corporatized, and Doman AB (100\% state-owned) was established with forest landholdings of 3.4 million ha while 0.7 million ha of forest was retained by the National Property Board. In 1993 Doman AB acquired ASSI AB (100\% stateowned forest company), which owned manufacturing facilities, and AssiDoman AB (100\% state-owned) was formed to own forest land, operations, and manufacturing facilities. The objectives behind this change were an internationally strong Swedish forestry company, enhanced use of virgin fibre, less dependence on business cycles, and self-sufficiency in wood. In 1994 the state reduced its position in AssiDoman to $51 \%$.

In 1999, about $25 \%$ of the AssiDoman forest land was transferred to Sveaskog AB, all the shares of which were acquired by the state, and the state reduced its position in AssiDoman to $35 \%$. The objectives of this move were (i) to explore the possibilities of land swaps with private land owners; (ii) to set aside more areas for environmental purposes such as nature conservation and recreation; and (iii) to encourage more competition for raw material, especially sawlogs (Asserståhl 2006). In 2001 AssiDoman was subsumed by Sveaskog AB, which is totally state-owned. With this change, the structure of forest ownership in Sweden became $49 \%$ private woodlot owners, $25 \%$ private companies, $18 \%$ state, and $8 \%$ others.

Sveaskog $\mathrm{AB}$ continues to sell forest land to small private owners and to buy large tracts of forest land. At present Sveaskog owns 4.3 million ha of land of which 3.2 million is productive forest land, i.e., $15 \%$ of the productive forest land of Sweden. Sveaskog activities include: (i) selling and buying wood; (ii) providing forestry services; (iii) leasing land and water assets for the purposes of hunting rights, fishing rights, agriculture lease, residential lease, installation lease, land lease, and rental; and (iv) establishment of wind power.
Sveaskog puts a large emphasis on research and development. It owns $50 \%$ of Setra Group $\mathrm{AB}$, the largest wood product company in Sweden. (All information in this paragraph was taken from the Sveaskog's Web site ${ }^{2}$.)

Corporatization and privatization of plantations in New Zealand Since the emergence of the environmental movement in the 1970s and early 1980s, the New Zealand Forest Service (NZFS) faced many criticisms and challenges, such as dissatisfaction with the management of indigenous forest (Kirkland 1988, Roche 1990), the Auditor-General's criticism of the department's accounting system (Roche 1990), and the inadequacy of the accounting system for purposes of commercial accounting and valuation of forest resources (O'Loughlin 2008). Upon the arrival of the new Labour Government in 1984, the Treasury criticized government departments for a lack of defined goals, effective controls, and freedom in operations. It proposed a market-oriented approach to forestry activities and suggested that the commercial activities of the NZFS should be transferred to a separate state-owned enterprise. The new Labour Government immediately embraced a market-oriented approach and introduced wide-ranging economic reforms, including removal of subsidies to agriculture and forestry and a new tax regime unfavourable to forestry. The government decided in September 1985 to separate the commercial and non-commercial functions of the NZFS (Kirkland 1988, Roche 1990). On April 1, 1987 the NZFS was dissolved and 3 new organizations were created: (i) the New Zealand Forestry Corporation (NZFC) to administer state forest production and wood processing; (ii) the Ministry of Forestry to undertake the sectoral and regulatory functions of the NZFS; and (iii) the Department of Conservation to administer conservation lands, including indigenous forests. The lands and forests under the control of the NZFS were assigned to the New Zealand Forestry Corporation and the Department of Conservation depending on the main objective of forest management. The NZFC consisted of 2 subsidiaries: New Zealand Timberlands with responsibility for managing and harvesting the 550000 ha of plantation forests and Pro$\log$ Industries Ltd. with responsibility for processing timber at its 2 sawmills at Waipa and Conical Hill (O’Loughlin 2008). The social costs of dismantling the NZFS were extremely high (O'Loughlin 2008), but no real estimates are available. Although it was financially quite successful (Birchfield and Grant 1993), the NZFC was a very short-lived organization.

With the re-election of the Labour Government in 1987, the Treasury indicated various residual problems with the State Owned Enterprises (SOEs), including the NZFC, and suggested a full private sector approach. One of the major problems was a valuation of the Crown businesses transferred to the SOEs. In addition to the Treasury's assessment of the SOEs, New Zealand's gross public debt of about $75 \%$ of GDP and the annual debt service of about NZ $\$ 4.5$ billion were among the main incentives to privatize the public sector. The government appointed the NZFC as the principal sales agent, and in October 1989, the corporation issued the "Sale of State Owned Forests in New Zealand" prospectus. The sale process was complicated by Treaty of Waitangi obligations, but the

${ }^{2}$ www.sveaskog.se/en/ [Accessed March 20, 2009] 
government reached an agreement with the Maori in 1989 that enabled the Crown to sell the existing tree crops and associated assets for an immediate payment and annual land rental payments to be placed in a trust. The main feature of the agreement was preservation of Maori rights without appreciably weakening the interest of the bidders in the sales process (Birchfield and Grant 1993). The government agreements with Tasman Forests and Carter Holt Harvey, New Zealand's largest private forestry companies at that time, also delayed the process of sale, and this conflict was finally resolved by sale of those forests to the company (Birchfield and Grant 1993). The sales were structured so that the buyer would buy the existing trees, buildings and other fixed assets while the land remained the Crown's property and could be leased to the purchaser for any legal purpose, including replanting. The sale instrument was called a Crown Forestry License. The term of the license was 35 years, a rotation period for radiata pine plantations. The term of the license could be extended by 1 year, each year, unless notice was given to the contrary. If the land was not liable to a Maori ownership claim, the license term would be extended by adding a further term of 35 years (Kirkland and Berg 1997). The sale involved about 90 individual state forests and 554 214 ha of plantations, about $81 \%$ of which were radiata pine plantations. The first sale process was finalized in November 1990, and the fixed assets and rights on 246700 ha of land were sold for NZ\$1.027 million (O’Loughlin 2008). An area of about 303600 ha of state forest, mostly in central North Island, could not be sold due to unacceptably low bids (Birchfield and Grant 1993). Hence, a subsidiary of the NZFC-NZ Timberlands Bay of Plenty Ltd-was established to manage unsold state forests in North Island and Timberlands West Coast Ltd.was formed for the West Coast. In 1992, most of the remaining state forests outside the Bay of Plenty, about 97 000 ha, were sold to Rayonier Incorporated for NZ\$366 million. In this sale the buyer was obligated to replant after harvesting, which was a new condition of sale. In 1996, Kaingaroa Forest and the associated forests in the Bay of Plenty (about $190000 \mathrm{ha}$ ) and 2 wood-processing plants were sold to New Zealand-based Fletcher Challenge Ltd. for NZ\$2.03 billion. The sale conditions were similar to those of the 1991 sales. With the 1996 sale, the bulk of the formerly state-owned plantations were sold (trees only), with about $4 \%$ of the total plantations left with the state.

On re-election in 1987 the Labour Government set a target of NZ\$14 billion from the sale of public assets to lower the debt. The government was quite successful, raising NZ\$12 billion by 1992 (Douglas 1993). The sale of state forests between 1990 and 1996 contributed approximately NZ\$3.5 billion. These changes resulted in 2 long-term impacts: loss of a multiple-use approach to forestry and uncertainty about the long-term vision for forestry (Perley 2003).

\section{Commercialization, corporatization and privatization of the public plantation estate in South Africa}

In the late 1990s, South Africa had approximately 1.5 million ha of commercial plantations (52\% pine and $39 \%$ eucalyptus), and prior to the start of the process of privatization the ownership of plantations was 30\% state, $47 \% 2$ large forest companies (Sappi and Mondi), 22\% small private companies and big farmers, and 1\% small growers (Mayers et al. 2001). The publicly owned plantations have 2 components: the plantations established and managed by the former Forestry Department and the plantations of the former Homelands. After the reunification of South Africa in 1994, all homelands plantations (about $155000 \mathrm{ha}$ ) were transferred to the national Department of Water Affairs and Forestry-DWAF (Dlomo and Pitcher 2005).

There had been discussions about the role of the state in forest plantations since the early 1980s, and the new forest policy in 1996 provided a clear direction and impetus to divest the state's plantations. The process started in 1983, with the appointment of an Interdepartmental Committee to investigate the transfer of the state's plantation activities to a Corporation, and prior to the 1996 Forest Policy, a 3-stage (commercialization, corporatization, and privatization) process was envisaged for the forest assets (Mayers et al. 2001, Dlomo and Pitcher 2005). The commercialization began in 1985 with the adoption of a new "trading account" by the Forestry Department. The new accounting system enabled the Department to identify timber income and production costs separately, and the Department was also allowed to retain related revenue (Mayers et al. 2001). The process of corporatization began in 1989 with the presentation of a draft bill on the creation of a National Forestry Corporation. The South Africa Forest Corporation Limited (SAFCOL) was incorporated in September 1992. In 1993, SAFCOL and the government agreed on the process for the transfer of assets and staff. After that, SAFCOL commenced commercial operations and the process necessary to sell off all or part of the government's shareholding.

Following the 1994 elections, discussions started about an approach to combine the privatization of plantation assets with the SAFCOL process. In late 1998, the government formally approved a single process to privatize all its plantation assets (those managed by both SAFCOL and DWAF). The process involved a phased approach, dividing all the state's plantations into 3 categories (Dlomo and Pitcher 2005):

(i) the entire SAFCOL estate (386 $476 \mathrm{ha}$ ) combined with those former Homelands plantations (about 70000 ha) that were so closely associated with particular SAFCOL assets as to make their combination logical;

(ii) the balance of the commercially viable DWAF plantations (approximately $70000 \mathrm{ha}$ ); and

(iii) about 120 small scattered plantations, extending over $15000 \mathrm{ha}$, producing non-commercial material that is extensively utilized by local people.

It was decided to concentrate first on the first category of assets - joint SAFCOL/DWAF assets-and to complete this process before putting other assets on the market. The combined SAFCOL/DWAF assets were divided into 7 "packages," each representing a logical business unit and a "Special Purpose Vehicle" (SPV) was created for each package. It was decided that $25 \%$ shares in each SPV would be held by non-private agencies-government (10\%), workers (9\%) and the National Empowerment Fund (6\%), 75\% will be sold to the private sector. Private investors were then invited to bid for a $75 \%$ shareholding (of which at least $10 \%$ needed to be blackowned) in any combination or all 7 SVPs. One of the important features of these SVPs was that ownership of the land under plantations remained with the state, and the investors were offered the use-rights only through a long-term lease. In 
the 2001 sale, in which 7 SPVs amounting to 321826 ha of plantations, were offered for sale, only 2 SPVs (total plantation area of $90377 \mathrm{ha}$ ) were sold (Dlomo and Pitcher 2005, Table 10.1). In fact, these were leases, and not sales, of land. The lease included the following:

(i) lease duration of minimum 70 years;

(ii) payment of market-related rent to use the land; the value of standing trees is not included in the calculation of the land rent;

(iii) full undisturbed possession of the land subject to the Forest Act provision that allows public access for cultural, recreational, and spiritual purposes;

(iv) license covers all activities, including silviculture, ecotourism, hunting, and quarrying; the lease holder may issue license to third parties for some of these activities;

(v) in the event of a successful land claim, the claimant receives title to the land and the rent, but the lease remains in place. However, the claimant can challenge this in court and if the claimant is successful the state must compensate the leaseholder for losses (Dlomo and Pitcher 2005).

\section{Commercialization, corporatization and privatization of plantations in Australia}

The conservation movement in Australia grew in the late 1960 s and 1970s and management of native forests became a contentious issue. A large proportion of state forest land was moved to conservation areas in the 1970s and 1980s. As a result of reduced timber production from native forests, the Commonwealth (federal) Government and state governments put considerable emphasis on expansion of plantations through tax incentive mechanisms. In addition, other issues, such as the lack of economic/commercial focus and efficiency among state forest agencies and separation of management and administration responsibilities, also gained the momentum in the 1980s. As a result, the Commonwealth and State governments announced a National Forest Policy Statement (NFPS) in 1992. The main feature of this policy statement was integrated management of native forests through Regional Forest Agreements (RFAs), and other key features included expansion of softwood and hardwood plantations and moving to market-based pricing of forest resources. The key outcome of the NFPS was a set of 10 RFAs in 4 states-Western Australia, Victoria, Tasmania and New South Waleswhich cover about 23 million ha of productive forest land (Pollard 2007). The RFA are 20-year agreements that try to balance environmental, social, economic, and heritage values and provide certainty for forest-based industries, forestdependent communities, and conservation efforts.

After the recession that followed Black Monday (October $19,1987)$ the government focused on widespread economic reforms. The main objective of the federal policy during this period was increasing the role of market forces and reducing the role of the state. The Government announced the National Competition Policy (NCP) in 1995. The main features of the policy were to provide a level playing field for the private sector by promoting efficient competition between the public and private sectors and separation of regulatory and commercial functions (Pollard 2007, Nelson and Nikolakis 2008). As result of the NFPS and the NCP, most state forest agencies were structured to operate as commercial entities, called Government Trading Enterprises (GTEs) or Government Business Enterprises (GBEs) within government departments. The different states made different choices. New South Wales (NSW) (Forests NSW in 1992), Tasmania (Forestry Tasmania in 1994), and Western Australia (Forest Products Commission in 2000) opted for GTEs and South Australia (Forestry South Australia in 2001) for corporation (Nelson and Nikolakis 2008). Queensland and Victoria started with GTEs but later moved to corporation. Similarly, different states took different approaches for regulatory and policy responsibilities.

In 1995, Queensland started with a business unit within the Department of Primary Industries called DPI Forestry, which was responsible for managing and marketing all commercial forest production on both native and public land. However, DPI Forestry had negative returns on assets from 2003 to 2006. In May 2006, Forestry Plantations Queensland (FPQ), a state-owned corporation, was created for operations on plantation estates, and a new business unit in the Department of Natural Resources and Water (NRMW) called NRMW Forest Products was responsible for business activities on native forests.

In 1993, Victoria created a state-owned corporation, Victorian Plantations Corporation, which was given rights to trees, but not land, on 114000 ha of softwood plantations. In 1998, these plantations (trees only, not land) were sold to Hancock Timber, which retained the state log supply commitment. In 1999, Forestry Victoria, an internal business unit, was created to manage commercial activities on state forests (Pollard 2007). In 2002, the Victorian Government released the "Our Forests our Future" Policy addressing many principles of the NCP and criticisms of the Australian Conservation Foundation's 2001 Review (Pollard 2007). In 2004, the Victorian Government reorganized its operations and VicForests, a newly created state corporation became responsible for commercial activities on state forests, the Department of Primary Industries became responsible for commercial forest policy advice to government, and the Department of Sustainability and Environment (DSE) for conservation, planning, regulations, and monitoring (Pollard 2007). The DSE provides area-based allocation to VicForests; VicForests determines timber volume and prepares Timber Release Plans (TRPs), including specifications of individual coupes. The TRPs are approved by the DSE. VicForests is responsible for harvesting, hauling, transportation of timber, and regeneration of the area. VicForests started with sealed-bid auctions in 2006 and later introduced online auctions. In 3 years of operations (2005-06, 2006-07, and 2007-08), VicForests harvested $1.8,1.6$, and 1.9 million $\mathrm{m}^{3}$ of timber, and made a net profit after tax of $\$ 2085 \mathrm{~K},-\$ 17 \mathrm{~K}$, and $\$ 538 \mathrm{~K}$, respectively (VicForests 2008)

In 2001, the Australian Conservation Foundation evaluated the performance of the different states with respect to the objectives of the NCP (1995), and Nelson and Nikolakis (2008) revised that assessment on the basis of new data. According to the Nelson and Nikolakis (2008) assessment, Victoria has met all 4 objectives-(i) separation of regulatory and policy functions from commercial functions; (ii) independent monitoring and enforcement of plans, codes, and standards; (iii) independent and transparent setting of reserve prices; and (iv) separation of native forest logging from the 
promotion of private plantations. Queensland has achieved the first, second, and fourth objectives; Western Australia has met the first and second objectives, and South Australia the forth objective; and all these states have made progress on other objectives. NSW and Tasmania have not achieved any of these objectives but have made progress on all 4 objectives.

\section{Creation of a forest enterprise as part of the Forest Commission of the United Kingdom}

Most of the following discussion is based on Grundy (2005). The Forestry Commission (FC), a state agency, was established in 1919 to promote afforestation in the United Kingdom (UK). The FC planned to meet afforestation targets by buying land for planting and through incentives to private landowners for plantations. The FC afforestation policies, to a degree quite successful in achieving its objectives, came under increasing criticism during the 1980s. In 1988, the government eliminated tax incentives for plantations and planting grants, and began to focus on a wider range of specific types of plantations, such as small-scale wood lots, broadleaved species, and community and recreation woods. The FC's own afforestation program continued from 1920 to about 1990. However, afforestation by the state was discontinued based on a perception that the private sector is a better manager of commercial activities, and the FC began disposing of some forests. The state-led partnership with the private sector succeeded in establishing over 1.5 million ha of plantations, of mainly non-native coniferous species. These plantations, combined with other woodlands and forests in private ownership, raised the area under trees from 5\% (at the time of establishment of the FC) to about $11 \%$. The state-owned plantations increased from about 0 to nearly 1 million ha. In the 1980 s and early 1990s, about $10 \%$ of the state-owned plantations, consisting of a large number of small plantations, were sold to neighbouring landowners in the hope that they could easily integrate the plantations into their existing estates and manage them efficiently. At the same time, demand for recreational and environmental values from state plantations was growing. Although environmental non-government organizations (ENGOs) and the general public believed that the FC would be more effective than the private sector in the provision of these values, the government introduced schemes to encourage provision of recreational and environmental services from private plantations.

The expectation of the FC and the Treasury was that the plantations would yield a positive return. However, due to the FC's multiple functions-departmental, regulatory, and promotional-and the very long investment period (almost a century), calculation of financial returns was almost impossible. In 1994 the government established a review mission to examine the case for privatizing state plantations. The review report was not published, but the main features of the review are discussed below.

The review discussed 3 options: sale of plantations, creation of a corporation, and creation of a state agency responsible for managing the plantations. Sale was found not to be a viable option for various reasons. First, the sale of all the plantations to one or a few buyers was problematic due to the scale off transactions and low number of bidders. Second, forest industry preferred to deal with a well-known supplier rather than with new and probably powerful suppliers. Third, the existing forest companies were reticent to tie up their capital in plantations. Fourth, it would have taken a very long time to sell 1 million ha. Incorporation also had many obstacles. First, as the commercial operations of the FC were mixed up with its non-commercial operations and regulatory, promotion, and departmental activities, it was almost impossible to evaluate the commercial viability of a stand-alone corporation. Second, the necessary information-annual commercial accounts for 3 years-for a stock market valuation was not there. Third, the experience of New Zealand, South Africa and Sweden suggested that the process of creation of a commercial forestry corporation from a government department requires many years to complete. Fourth, the low rate of return on forestry activities suggested that a corporation may need government subsidies indefinitely. In addition, privatization was opposed by almost every sector-forest users, the ENGOs, private owners, forest industry, and politicians.

The outcome was the creation of a new agency - the Forest Enterprise (FE) - carved out of the FC. The FE was made responsible for the management of state-owned plantations without any departmental, regulatory or other functions. The FE is answerable to the FC, and it manages state-owned plantations according to the objectives set by the government for timber production, biodiversity, and landscape values, and for efficiency and profitability. The FE can contract out its operations or it can employ contractors on the work it manages. The FE has no manufacturing operations. The experience of the UK suggests that there can be substantial gains in efficiency and effectiveness through restructuring government forest departments by separating regulation from forest management.

\section{Creation of forestry enterprises within the state forestry organizations of Germany}

Most of the following is based on personal communication with Professor Martin Moog ${ }^{3}$. Ownership of forest land in Germany, about 11 million ha, is $47 \%$ private, $30 \%$ state (Bundeslaender), 4\% federal (Bund), and 19\% communal (Roering 2004). There are about 10000 communal forest owners, mainly municipalities, and about 1.3 million private forest owners that are mostly farmers (Roering 2004). Forest product manufacturers own very little forest land in Germany. Forests are an important resource in Germany's economy. After the Second World War, the owners of forest resources were in a much better situation than other people in Germany. However, with increasing wages and declining timber prices, the economic situation of the owners of forest resources changed in the 1960s. In the early 1970s, most of the state forest units (Forstämter) were significantly reduced. Timber prices increased in the 1980s. A catastrophic storm in March 1990 blew down 3 times the amount of timber normally harvested per year. The storm was followed by a bark beetle problem. Timber prices went down sharply. The costs of reforestation were very high. Other factors-such as the overall economic situation of the country, the scarcity of funds in state budgets in general and for forestry operations specifically, general public opinion about non-flexibility and inefficiency of state agencies, demand for separation of management and administration, and support of the concept of

${ }^{3}$ Institute of Forest Economics, Technische Universität München, Germany, Consulted in March 2009 
the "slim state" in countries such as Australia, New Zealand, Sweden, the United Kingdom and the United Statesprovided impetus for forestry reforms in Germany. A second storm in late December 1999 provided further impetus for discussions of reforms.

The outcome of these discussions was the separation of ownership and management of state forests and administration of private forests. There was strong opposition from environmental groups and lack of political support for sale of state forests. Prior to the forestry reforms, forests in all German states were under state administration. Organizations called Regiebetrieb were responsible for management of state forests, forest administration and policing, and forest consulting and promotion of non-state forests. By 2006, most German states implemented a new organizational structureAnstalten öffentlichen Rechts or Landesanstalt-for the management of the state forests. Anstalten öffentlichen Rechts are similar to business units (forestry enterprise) within the state organizations. They are not independent legal entities and are under the full control of the state governments. State budgets specify both the funding available to these organizations and the payments to be returned to the states. The people working for these organizations are the same as before. The rights granted to these enterprises vary from state to state, ranging from comprehensive rights to usufruct rights only. The single exception is in the very small state of Saarland, where forest management is undertaken by Saaforst $\mathrm{GmbH}$ (a Limited company).

The reforms were intended to improve economic efficiency, or at least reduce the cost of operations. Other reasons for the reforms included increased access to new non-timber business areas and local taxation issues. There is no study to

Table 1. Organizations responsible for forest related activities in selected countries

\begin{tabular}{lccccc}
\hline Function & Bulgaria & Croatia & Latvia & Romania & Slovakia \\
\hline Regulatory (Policy and legislation) & & & & & \\
Policy setting & M & M & M & M & M \\
Legislation and regulation & M & M & D & M, S & M \\
Legal Enforcement & D & D, O & D & M, S, O & D \\
Forest management & & & & & \\
Management planning & D & S & D & R, P & S, P \\
Fire and Pest management & D & D, O & D & S & S \\
Inventory & D & S & D & S & S, P \\
Road construction and maintenance & D & S & S & M, S & S \\
Regeneration & D & S & S & S & S \\
Management for recreation & D, O & S & S & S & S \\
Management for conservation & D, O & B & B & S, B, C & B \\
Management for environmental & & & & & S \\
$\quad$ services - watershed protection & D & S & S & S & S \\
Other services & & & & & \\
Sale of timber from state forests & D & S & S & S & S \\
Sale of non-timber from state forests & D & S & S & S & S \\
Extension services to private owners & N & N & P & D, S & N \\
\hline
\end{tabular}

\section{Notes:}

B: Biodiversity Conservation Department

C: Partly delegated to communities or private users

D: Department for Forestry

M: Ministry responsible for forestry

$\mathrm{N}$ : Service is not effectively provided

Source: The World Bank 2005 support a case that the new organizations have increased economic efficiency. However, operational changes have been made. For example, before the reforms a state forest agency used to undertake all forest management functions by itself. After reforms, there has been a trend to contracting out some operations, particularly in harvest and hauling. Timber supply contracts are let on a short-term basis, generally from half a year to one year, and prices are fixed based on market prices. Higher-valued wood is made available on the request of customers, and highest-value timber, such as older oaks, through competitive bidding. There is no evidence that these reforms have attracted more investment to the forestry sector.

\section{Forest tenure reforms in transition economies}

One of the main features of tenure reforms in Estonia, Hungary, Latvia, Lithuania, Poland and Romania has been the separation of commercial and regulatory forestry functions. In the 3 Baltic countries-Estonia, Latvia and Lithuaniapolicy formulation and field implementation have been also separated. A comparative analysis of the nature of organizations responsible for forest-related policy, legislation, and management activities in the selected countries of this region is presented in Table 1. As is evident from the table, state enterprises in Croatia, Latvia, Romania and Slovakia are heavily involved in forest management activities, although there is considerable diversity among these countries. For example, forest management planning is done by a state enterprise in Croatia, by a department in Latvia, by a forest research institution and a private agency in Romania, and by a state enterprise and a private agency in Slovakia.

The outcomes of the separation of commercial functions from regulatory functions have been mixed. For example, in the case of that Latvian state forest enterprise, turnover increased by $40 \%$ and profit tripled in the second year of its operation, while in Estonia the state forest enterprise doubled its turnover and tripled its investment in a period of 5 years (The World Bank 2005). However, in Poland, the state forest enterprise has been in a difficult financial situation and has been unable to achieve financial returns similar to other state agencies (The World Bank 2005). These financial measures of success are quite narrow, but they may reflect the impacts of wider economic liberalization and not only of forestry reforms. For example, timber markets in Estonia and Latvia have expanded immensely in the last 5 years and the state forest enterprises were well placed to take the advantage of these markets (The World Bank 2005). In addition, the commercial objectives of state enterprises pose new challenges to regulatory institutions. First is reconciliation of the need to realize profits with the need to protect long-term forest 
health. Second is conflict between state agencies with different mandates and the resulting economic inefficiencies. Third, challenges to and performance of the newly created state enterprises depend on the social, economic, and legal environments in which they exist. For example, the challenges for a state enterprise in a country where it manages only a small forest area and private enterprises manage a large forest area are quite different than the challenges in a country where a large forest area is under state control. Separation of regulatory and commercial functions is a complex process and effective management of this process can be very difficult to achieve.

\section{Discussion}

Wide-ranging tenure reforms around the globe, specifically in developed countries, suggest that no single tenure arrangement, including private or public ownership, can be economically successful in all countries and regions. All tenure reforms presented in the previous section might have been designed to enhance economic efficiency and competitiveness of forestry sector in general, but they also had specific objectives in specific economic, social, organizational, and political contexts. The specific objectives and diverse contexts contributed to diversity of tenure arrangements. Hence, it is unreasonable to suggest that a particular tenure form will be suitable for Canada, but we can draw some inferences from all types of tenure reforms and these can be used by Canadian policy-makers and resource managers. Inferences related to every type of tenure reform are discussed below.

\section{State-owned forest company}

Sveaskog AB of Sweden, a fully state-owned company, owns about $15 \%$ of the productive forest land of Sweden and manages it for multiple functions. The company is involved in multiple activities, ranging from selling and buying wood to development of wind power. The company also owns $50 \%$ of the shares in the Setra Group AB, whose Return on Capital Employed (ROCE) in 2007 was the highest (25.2\%) among all forest companies in the world. The Sveaskog AB example clearly demonstrates that the type of ownership of the forest land or business is immaterial-government-owned companies can perform as well as private companies.

\section{Privatization of plantations and not forests}

Advocates of selling Crown forest lands to private companies in Canada generally refer to the cases of Australia and New Zealand, where tenure reforms were known as privatization of forests. In reality, the experience of forest tenure reforms in Australia, New Zealand and South Africa provide a very good case against the sale of natural forests. The key features and experiences are summarized below.

In all 3 countries, tenure reforms were related to plantations and not natural forests; only the ownership of existing trees was sold and not the ownership of land. The total plantation areas involved in each country were in the range of 100000 ha to 500000 ha. It was not easy to find buyerseven for such small areas. In Australia, only the state of Victoria proceeded with the sale and only the trees on 114000 ha of softwood plantations were sold to Hancock Timber. In the case of New Zealand, it almost took 6 years to find buyers, and many sales were conducted through bilateral negotiations- not through auctions-due to the lack of interested parties. Hence, the prices received during these sales cannot be called competitive market prices. In the first sale in South Africa, only 2 out of 7 Special Purpose Vehicles (SPVs) were sold. The plantations sales efforts in all 3 countries were specifically for radiata pine and eucalyptus plantations. Both species are fast-growing with mean annual increments in these 3 countries in the range of $15 \mathrm{~m}^{3} / \mathrm{ha} /$ year to $25 \mathrm{~m}^{3} / \mathrm{ha} /$ year, while the mean annual increment of Canadian forests is about $2.5 \mathrm{~m}^{3} /$ ha/year.

One of the key issues related to sale of plantations or forest land is the valuation of assets to be sold in the market. The valuation of plantations, which are established mainly for timber purposes, is difficult, while the valuation of forest land is highly complex due to a large number of associated ecosystem goods and services, many of which are public goods. In addition, the choice of discount rate in the context of public goods and many life-saving services adds another complexity. Sale of forests, without proper valuation, will result in dissipation of public assets and not in economic efficiency of forest management. Even if we assume that the world's best economic minds will be able to correctly value forest resources, which is almost impossible, why would a private agency be willing to pay for public goods when it knows that it cannot charge for these goods and services? The government of the UK decided against the sale of plantations and the reasons attributed to its decision-the small number of buyers, the forest industry's preference for the government to continue as a timber supplier, the forest industry's reluctance to buy forest land, and the long time required to organize sales-are very relevant to other jurisdictions like Canada.

\section{Corporatization of forest management activities}

New Zealand and South Africa created plantation corporations as an intermediate step to privatization of plantations. The New Zealand Forest Corporation doubled the operating surplus per cubic metre of wood produced over its lifespan of 3.5 years, but the Treasury was not satisfied with the corporation's valuation of assets. VicForests in Australia made a net profit in 2 years and loss in one year in its first 3 years. The creation of forest corporations, irrespective of their economic performance, has many complex issues. First, the commercial operations of state forest agencies are normally mixed up with non-commercial operations, and therefore it is almost impossible to evaluate the commercial viability of a stand-alone corporation beforehand. Second, in some countries it may be necessary to have annual commercial accounts of the existing state agency for 3 years for the creation of a forest corporation (for stock market valuation), and state agencies do not maintain commercial accounts. Third, the valuation of forest assets is the biggest challenge for transfer from state agency to corporation, and without proper valuation of transfer assets financial analysis of the corporation operations will be misleading. Fourth, the process of creating a forest corporation out of a government department may take many years due to differences in accounting systems, staff structures, and organizational cultures. Finally, the low rate of return on forestry activities suggests that the corporation may need government subsidies indefinitely. 
Creation of separate business enterprise within the state forestry agency

Creation of a separate business enterprise within the state forestry agency is the leading mode of recent forest tenure reforms. Many countries, such as Germany and the United Kingdom, many states in Australia, and many countries with transition economies (such as Croatia, Estonia, Latvia, Romania and Slovakia) have created state enterprises for commercial activities within the forestry agencies.

The creation of state enterprises has some advantages compared to corporatization and privatization. First, it avoids the key problem of valuation of forest assets because forest assets are not being transferred to another agency. Second, it offers flexibility to state agencies in terms of selection of forest management activities that are to be transferred to these state enterprises; some examples are given in Table 1. Third, state enterprises generally have a high degree of acceptability by the public and environmental groups as well by from politicians and forest industry. Finally, the cost of creation of state enterprises within the state agency is much lower than the cost of corporatization and privatization. However, creation of state enterprises can be criticized for lack of professionalism, continuation of government control, for having the same organizational culture as the state agency, and for lack of clarity about the division of responsibilities or for having overlapping responsibilities. These criticisms may be true in some cases, but the following observations are also worthy of consideration:

"In fact there is very little empirical research which shows that organizational structures, by themselves and in isolation, are the key element to a successful reform process. To the contrary, the evidence strongly suggests that the functional form of a forest organization simply does not matter. Very different models can succeed, and very different models can fail... To argue that any of these models are 'better' than others is to ignore the frameworks of accountability and governance which underpin each of them, and which are derived from a range of political, economic, and physical factors which are in many respects unique and which have historical, social, and cultural elements to them." (The World Bank 2005)

These observations are fully supported by the diversity of forest tenure arrangements among and within countries around the globe.

\section{Conclusions}

Forest tenure does not mean ownership of forests, but it means property rights arrangements for different attributes of forest ecosystems. An optimal forest tenure is an optimal mix of private and public rights and duties with respect to different attributes of forest ecosystems, and this optimal mix will vary with social, economic, ecological, organizational, and political context (Kant 2000). These contextual factors are dynamic and, therefore, forest tenures should be modified regularly to maintain their optimality (Kant 2000). The dynamics of contextual factors is expected to lead to a totally different forest sector in the next 2 or 3 decades. Hence, policy-makers and forest managers must develop innovative forest tenure arrangement to meet these challenges. I propose 9 key guiding principles for forest tenure reforms in Canada.
1. New forest tenures need to meet future challenges, and the future of the forest industry will be dominated by bio-composites, bio-fuels, and bio-refinery. Conventional wood commodities will play a smaller role. Hence, forest tenure reforms should not only account for these emerging industrial trends, but should set the stage for Canadian leadership in the global forest sector.

2. Forest tenures should be designed to optimize returns from all forest attributes and not from timber only.

3. The forest sector, including the forest industry, is in a transitional stage. Although there are indications of future trends, the picture is not completely clear, specifically in terms of the dominance of bio-products. In addition, climate change may bring some surprises to the forestry sector. Hence, forest tenure reforms should give the highest priority to flexibility, diversity, and adaptiveness.

4. The focus of forest tenures should be to promote forest industry's competitiveness and only the fittest companies/industries should survive. Governments should create forest tenures not for a secure supply of timber at fixed prices, but for a secure supply of timber for those who can afford it at competitive prices; this means that interested companies have to pay for security of supply. This will require diversity and flexibility in forest tenures.

5. Forest managers must move beyond the concept of biologically determined annual allowable cut. Forest tenures should allow the determination of annual harvest based on economic and biological factors separately, and the lowest computed value should be used. The reduced timber harvest may solve the softwood lumber dispute problem; it would increase softwood lumber prices, which should lead to increased economic returns to the competitive forest industry; and it would provide higher economic returns per unit of timber harvested to the owner of forest. Environmentalist would be happy with this approach and it would provide more space to other forest values. A negative side effect would be the closure of inefficient mills leading to increased unemployment in some communities. However, this is not an uncommon phenomenon in developed economies and is, in fact, presently being faced by all communities.

6. Nanotechnology has revolutionized the use of fibre from trees and other biological sources and this will significantly increase the value of fibre from trees. These technological changes are also expected to create more jobs per cubic metre of timber. Hence, future tenures should be focused on maximizing the economic value from wood fibre and not on maximizing the timber harvest.

7. Forest management, timber allocation and harvesting are inter-dependent and non-separable and, therefore, forest tenures have to deal with them jointly. However, this does not mean that the same agency must deal with all aspects.

8. Forest tenures provide an institutional framework for forest management and timber allocation and harvesting. Organizations translate this institutional framework into real actions and forest management outputs and outcomes. The evidence strongly suggests that the functional form of a forest organization simply does not 
matter; very different forms can succeed, though the same forms can also fail under different conditions. Hence, one should not make a prejudgment without a complete analysis. I suggest a SWOT (strengths, weaknesses, opportunities, and threats) analysis of all possible functional forms-corporations, state enterprises, government-owned forest company-for every province in Canada separately. Decisions should be based on that analysis.

9. Forest tenure is a highly complex issue that cannot be addressed properly and efficiently by either academic researchers or by forest managers and policy-makers alone. Academic researchers have in-depth theoretical knowledge but are far from practical realities, while policy-makers and resource managers have extensive knowledge of field realities but are not fully conversant in theoretical concepts. I suggest that provincial governments should constitute expert groups - without direct stakeholders-the mandate of which should be to carry out in-depth SWOT analysis of all institutional and organizational options. The expert groups cannot be substituted by consulting contracts.

In summary, all these principles provide inputs to designing the optimal mix of private and public rights and duties with respect to different attributes of forest ecosystem for a given context, and modify the mix to maintain its optimality with contextual dynamics. In some cases, this optimal mix may require allocation of more private rights to forest industry, Aboriginal people and local communities, and in other cases it may require strengthening of public rights. My argument, similar to Luckert (2009) and Vertinsky (2009), is that that the specifications of private and public property rights on Crown forest lands should be designed to provide flexibility (option to change the mix), diversity (to address the diversity of contextual factors), and adaptiveness (to address the dynamics of contextual factors) in forest tenures and to promote the sustainability and competitiveness of the forest sector.

\section{Acknowledgements}

A longer version of this paper was presented at the Annual General Body Meeting of the Ontario Professional Foresters Association (OPFA), April 23-24, 2009, Sudbury, Ontario. I am grateful for the support of the OPFA and Tony Jennings, its Executive Director. I am also grateful for inputs, comments, and suggestions from Profs. Judith Ajani, Karen Ing, Peter Kanowski, Martin Luckert, Martin Moog, Harry Nelson, and Ilan Vertinsky.

\section{References}

Arnot, C.D. 2007. Perceived tenure security and incentives for investment in Canadian forest tenures: A literature review and empirical analysis. M. Sc. Thesis, Department of Rural Economy, University of Alberta, Edmonton, AB.

Asserståhl, R. 2006. Privatizing state forests in Sweden. Presented at the BC Forum Symposium "Creating New Opportunities: Forest Tenure and Land Management in BC", November 1, 2006.

Birchfield, R.J. and I.E. Grant. 1993. Out of the woods - the restructuring and sale of New Zealand's state forests. GP Publications, Wellington, New Zealand. $250 \mathrm{p}$.

Clarke, J. 1997. Logging costs skyrocketing in BC. Logging and Sawmilling Journal 28(4): 5-6.
Dlomo, M and M. Pitcher. 2005. Juggling Social and Economic Goals: South Africa. In M. Garforth and J. Mayers (eds.). Plantation, Privatization, Poverty, and Power: Changing Ownership and Management of State Forests. pp. 223-245. Earthscan, London.

Douglas, R. 1993. Unfinished business. Random House New Zealand Ltd., Auckland, New Zealand. 305 p.

Grundy, D.2005. From plantation development to steward of the Nation's Forests: the UK In M. Garforth and J. Mayers (eds.). Plantation, Privatization, Poverty, and Power: Changing Ownership and Management of State Forests. pp. 246-265. Earthscan, London.

Haley, D. 1996. Paying the piper. The cost of the British Columbia Forest Practices Code. RPF Forum 3(5): 26-28.

Haley, D. and H. Nelson. 2007. Has the time come to rethink Canada's Crown forest tenure systems? The Forestry Chronicle 83(5): 630-641.

Kant, S. 2000. A dynamic approach to forest regimes in developing economies. Ecological Economics 32(2): 287-300.

Kant, S. 2009. Sale of Canada's public forests: Economically nonviable option. The Forestry Chronicle 85(6): 841-848.

Kirkland, A. 1988. The rise and fall of multiple-use forest management in NZ. NZ J. Forestry 33(1): 9-12.

Kirkland, A. and P. Berg. 1997. A century of state-honed enterprise. Profit Books Auckland, New Zealand. 176 p.

Lu, R. 2008. Preferences of Industry and Government Stakeholders for Characteristics of Forest Tenures in Canada - An Application of Best-worst Scaling Methods. M. Sc. Thesis, Department of Rural Economy, University of Alberta, Edmonton, AB.

Luckert, M. 2009. Considering Privatization in Canada's Forest Tenures. Presented at the OPFA Annual General Body Meeting, April 23-24, 2009, Sudbury, Ontario.

Mayers, J., J. Evan and T. Foy. 2001. Raising the Stakes: Impacts of privatization, certification and partnerships in South African forestry. IIED, London.

Minister's Council on Forest Sector Competitiveness. 2005. Final Report of the Minister's Council on Forest Sector Competitiveness, May 2005. Ontario Ministry of Natural Resources, Toronto, ON. 46 p. Nelson, H. and W. Nikolakis. 2008. How does corporatization improve performance of government agencies? Lessons from restructuring of state owned agencies in Australia. Draft Paper.

O'Loughlin, C. 2008. Institutional restructuring, reforms, and other changes within the New Zealand forestry sector since 1986. In P. Durst, C. Brown, J. Broadhead, R. Suzuki, R. Leslie and A. Inoguchi (eds.) Reinventing Forestry Agencies: Experiences of Institutional Restructure in Asia and the Pacific.

FAO, Rome.

Perley, C.J.K. 2003. Resourcism and preservationism in New Zealand forestry: an end to the dichotomy. NZ J. Forestry 48(2): 11-17.

Pollard, D. 2007. Issues in Corporatization in Australian Forestry, presented at the BC Forum on Forest Policy and Economics, BC, May 11, 2007.

Roche, M. 1990. History of New Zealand Forestry. GP Publications Ltd., Wellington, New Zealand. 466 p.

Roering, H.-W. 2004. Study of Forestry in Germany. Federal Research Centre for Forestry and Forest Products, Hamburg, Germany.

The World Bank. 2005. Forest Institutions in Transition: Experience and Lessons from Eastern Europe. PROFOR at the World Bank, Washington, DC.

Vertinsky, I. 2009. The Design of Tenure Institutions: The Challenge of Governing the Forests. Draft.

VicForests. 2008. VicForests Annual Report 2008. Available at www.vicforests.com.au/assets/docs/vicforests\%20annual\%20report \%202008.pdf [Accessed March 19, 2009]. 